\title{
Foreign Policy of the New Left: Explaining Brazil's Southern Partnerships*
}

\author{
Megan Pickup**
}

\section{Abstract}

The purpose of this study is to consider the relationship between domestic change and foreign policy in Brazil, a country seeking to become Latin America's hegemon, and achieve greater global status. It focuses on Brazil's partnerships with other countries in the Global South. It argues that, due to the combination of institutions and interests behind foreign policy-making in Brazil, there is no coherent project of South-South engagement. As a result, South-South ties tend to contradict the Brazilian government's foreign policy objective of acting as a global equaliser. The study also examines the drivers of Brazil's foreign conduct, and argues that the politico-economic determinants of foreign policy differ from those of domestic policy.

Keywords: Brazil; New Left; South-South Cooperation; Foreign Policy; Determinants.

\section{Introduction}

Many scholars have welcomed the turn to the Left - a post-neoliberal shift - in Latin America in recent years (see Levitsky

\footnotetext{
* Received on 30 October 2015 and approved for publication on 14 January 2016

** Carleton University, Ottawa, Canada; megan.pickup@ carleton.ca.
} 
and Roberts 2011; Cameron 2009; Weyland 2010). They have examined New Left governance in Latin American countries from various angles, seeking to establish its significance for domestic policy as well as foreign policy at the regional and global levels. Despite this attention, the precise manifestations of New Left foreign policy in the domestic and international relations domains, and the linkages between them, remain unclear.

As regards Brazil, some analysts have argued that the Workers' Party (Partido dos Trabalhadores, or PT) which rose to power with Luiz Inácio Lula da Silva in 2002 and still governs under Dilma Rousseff has been 'talking left abroad, and acting right at home' (Rohter 2010: 233). However, while there do appear to be key differences between the PT government's domestic and foreign conduct, the notion of 'talking left' abroad is also problematised by the extremely pragmatic course taken by foreign policy, which the PT government has explicitly recognised. For instance, in 2006, the then secretary-general of the Ministry of Foreign Affairs, Samuel Pinheiro Guimarães, declared: 'Brazil has to articulate political, economic and technological alliances with peripheral states of the international system to protect its interests' (quoted in Vigevani and Cepaluni 2007: 1314-5). This article seeks to explore more systematically how the rise to power of the New Left in Brazil ${ }^{1}$ has influenced its foreign conduct by examining its relations with other countries in the global South.

I will argue that Brazil's ties with other Southern countries are not only minimal, but also, where they are more substantial, plagued by various limitations. Instead of correcting global power asymmetries through strengthened South-South relations, which it set out to do, Brazil often replicates or exacerbates disadvantages of its Southern partners through its trade, investment, and development engagements. 
This article therefore investigates the determinants of Brazilian foreign policy in order to better understand the global implications of New Left governance in Brazil. While the outcomes of Brazilian foreign policy can be examined in isolation, I argue that examining foreign policy formation under the PT government provides greater insight into its foreign conduct, and why these two dimensions are so contradictory, especially in the longer term. In particular, favourable economic conditions initially allowed the PT government to pursue policy measures that accommodated various domestic interest groups, despite the potential for conflicting aims among them, but the political and economic crisis at the start of Rousseff's second term demanded that more difficult choices be made between competing interests.

By examining the determinants of foreign policy, the study introduces some of the 'natural' and external or structural variables that help to position Brazil as an active global player before focusing on four domestic variables, two institutional and two related to key constituencies. These variables are: the interaction between the government and the Ministry of Foreign Relations (Ministério das Relações Exteriores, or MRE), popularly known as Itamaraty; the interaction of the governing party with the MRE and the rest of the civil service; the role of business interests; and the influence of the social basis of government support, namely civil society, in foreign policy formation. Specifically, these factors explain why the promotion of Southern ties has been undertaken in such contradictory ways. The study further explores the differences between the determinants of foreign policy and domestic policy. This distinction is fundamental, as it helps to explain why the New Left experienced within Brazil is not the same as the Brazilian New Left experienced by the outside world.

The article begins with a brief summary of the domestic changes that brought the New Left to power. Next, it examines the foreign policy 
agenda of the New Left, implemented in Brazil since the PT's electoral victory in 2002. In particular, it focuses on the PT's efforts to improve relations with other countries in the Global South in areas such as trade and development cooperation. In order to draw out some of the global implications of these efforts, I examine the consequences of Brazilian engagement for 'other Southern giants', 'Southern states', and 'citizens of the South'. These labels risk eliding important differences among countries, but they do illustrate the wide variations in Brazilian influence. There is no clear sense of Brazil acting as a consistent partner in the South, despite the fact that a PT-led Brazil has explicitly cultivated these ties as part of a global agenda to remove imbalances in the world order. In the final section, I consider the politico-economic determinants of these intensified relations, arguing that factors such as the institutional role of the MRE play a key role in foreign policy decisions, thus helping to define their post-neoliberal character. This article considers foreign policy conduct from 2003 until 2014, during Lula da Silva's two terms in office, and Rousseff's first term. It relies primarily on secondary sources. I also studied speeches and other official documents recorded on the MRE website. Lastly, I drew on 26 semi-structured interviews conducted in Haiti in 2015 as part of a doctoral project on Brazilian South-South Cooperation. These interviews were conducted under conditions of anonymity with Haitian government officials as well as representatives of international organisations, bilateral development cooperation agencies, and civil society organisations.

\section{The rise to power of the New Left in Brazil}

The PT rose to power in 2002, with Lula da Silva serving as president for two terms until 2011. PT governance continued under Rousseff, Lula's hand-picked successor, who was re-elected for a second term 
in 2014. In 2011, she won a run-off election with 56\% of valid votes. In 2014, her margin shrank to $51.4 \%$ in a second round, following strengthened opposition to her on both the left and right (La Botz 2015). If she serves out her second term to 2018, the PT would have been in power for 16 years, the longest time any party has held power continuously in Brazilian history (La Botz 2015). However, following a corruption scandal, impeachment proceedings were brought against her in 2015, and at the time of writing it was not clear whether her presidency would survive.

The Latin American New Left in general appears to be in crisis, as signalled by the election of Mauricio Macri as Argentinian president. Nevertheless, even if this trend continues, post-neoliberal governments in the region would have created legacies that new governments would need to contend with, especially with respect to social policy.

The New Left in power in Brazil is difficult to understand. The transition from Fernando Henrique Cardoso's Brazilian Social Democratic Party (Partido da Social Democracia Brasileira, or PSDB), to the PT did not result in consistent breaks with previous policies (Burity 2006; Morais and Saad-Filho 2012). There have also been significant shifts in the tenor of PT administrations, including some dramatic discontinuities between both presidents' first and second terms. Foreign policy observers have widely noted that Rousseff seems disinterested in foreign policy (see Costa Vaz 2014). While I will seek to record changes in approach between Lula da Silva's and Rousseff's governments, the discussion of Brazil's relations with Southern partners primarily captures the continuities of their administrations. I regard this portrayal as appropriate as Rousseff's relative disinterest in foreign affairs has not always resulted in changed outcomes, and also because I seek to demonstrate Brazil's differentiated ties with the South, not to chart differences with select countries over time. In order to situate the 
foreign policy choices of Brazil's New Left, this section provides a brief overview of the contours of domestic policy under PT governments.

The PT government's economic policies have displayed the clearest continuities with the Cardoso government; especially during his first term, Lula da Silva displayed a similar attitude towards neoliberal economic reforms. For example, the priority given to the interests of the financial sector meant that controlling inflation was prioritised at the expense of growth and employment (Bin 2014). However, Lula da Silva did deviate in some respects from Cardoso's policies, inter alia by reintroducing policies with deep roots in Brazilian politics. This included the strengthening of public companies, which had largely been abandoned during the neoliberal period (de Almeida 2013). Paradoxically, given that conservative macroeconomic measures such as inflation control detract from employment, domestic investment policies took on a decidedly post-neoliberal character, such as by supporting labour-intensive economic sectors (Calvert and Pickup, forthcoming).

In general, both the Lula da Silva and Rousseff administrations have adopted 'neo-developmentalist' measures to ensure gains for domestic capital as well as workers (Boito and Berringer 2014). These policies have played a significant role in developing Brazil's internal markets, and have had major social ramifications, notably increases in the minimum wage, which have significantly reduced Brazil's extreme levels of inequality (Carrillo 2014; Costa, Fritz and Sproll 2015). However, certain problems inherent in the developmentalist agenda, including an overdependence on commodity exports, became harder to ignore after 2011, when economic growth began to slow (Costa, Fritz and Sproll 2015; La Botz 2015). Moreover, the benefits of PT policy have not been equally distributed; for example, state regulations aimed at encouraging labour market flexibility and attracting investments, 
such as pay increases linked to increased productivity, did not have the positive impacts that workers themselves had envisioned (Mello e Silva 2014).

It is in the realm of social policy that the PT government has been most celebrated by its supporters, academics and development professionals alike. Brazil is 'recognized as one of the countries with the most remarkable reductions of income inequalities over the last 15 years' (Leubolt 2013: 70). Indeed, scholars like de Oliveira (2010: 130) argue that the success of domestic social policies have prompted the 'export of social policies' via development cooperation to other countries in the Global South. While the differences between the PSDB and PT governments are more obvious in this area, conditional cash transfers were first introduced by Cardoso, and then expanded by the Lula administration as the world-renowned Bolsa Família (Family Grant) programme (Leubolt 2013). By 2013, Bolsa Família had reached more than 13 million families (Leubolt 2013: 75).

However, this form of social assistance, seen as the 'most dynamic sector of social spending', diminished government investments in other areas; before 2004, investments in social services as a whole actually declined (Leubolt 2013: 77). Investments in infrastructure have increased over time, partly as a result of a 2007 growth acceleration programme (Morais and Saad-Filho 2011), but questions remain about their quality. The 2013 protests by some 8.5 million people signalled 'personal aspirations revolving around public transportation, health care, housing, and employment and also the collective sentiment that the society could do better' (La Botz 2015: 5).

Economic and social policy also interact in important ways. As Leubolt (2013) states, the PT government's initial commitment to neoliberal economic reforms, and the consequent rise in interest 
rates, led to higher government debt repayments, which reduced the resources available for addressing social needs. Moreover, concentrating on social benefits for the poorest of the poor can create new forms of exclusion, as services are not guaranteed universally, and social solidarity may be lost as wealthier Brazilians pursue private services (Soares 2003, cited in Leubolt 2013). Recognition of this potential effect seems especially prescient given the polarisation in Brazilian society after the presidential elections in October 2014 in which Aécio Neves of the PSDB drew the support of the 'traditional' middle classes, while Rousseff benefited disproportionately from support by the lower and lower-middle classes (Rennó 2015). Soon after, a corruption scandal ${ }^{2}$ and continued protests shook Brazilians' confidence in her administration. An April 2015 survey found that $63 \%$ of Brazilians would support impeachment proceedings against her (Douglas 2015), and polling in the same month gave her the worst presidential approval rating in Brazilian history (Braig, Power and Rennó 2015).

While there are multiple reasons for the widespread discontent including the magnitude of the corruption scandal - the protests are also a product of deeper discontent with the PT government among the middle and upper classes. As one observer has noted, 'it is not "the Brazilian people" who are in the streets, but rather a very specific segment of the population whose economic interests are historically opposed to those of the majority' (Pitts 2015). Their indignation stems from the sentiment that the government has benefited the poor and the working class to their own detriment (Pitts 2015). Discontent is not limited to these classes, however, as the exhaustion of the developmentalist model also affects poorer classes. While social spending and increases in pensions linked to the minimum wage increased from $7.7 \%$ of the federal budget in 1995-8 to $9.2 \%$ in $1999-2011$, the increase in interest payments on government debt, combined with reductions in welfare spending in 
other areas, 'more than offset the increase in pensions and social assistance' (Bin 2014: 440).

Although New Left governance seems to be in growing crisis, the PT's ascent to power has resulted in a number of significant changes in a post-neoliberal or neo-developmentalist direction. These dynamics are in constant flux. Even if impeachment proceedings fail, it is clear that the repolarisation of Brazilian society will affect the extent to which policies associated with the New Left can be pursued in the future. Next, I turn to the PT's impact on Brazil's global role.

\section{The Brazilian New Left on the global stage}

The neo-developmentalist current, with its emphasis on state intervention to promote social inclusion, is also visible in the realm of foreign policy, with all its advantages and limitations. This section describes some of the key dimensions of Brazilian foreign policy in the economic, political and development spheres, before discussing the shift in approach through the prioritisation of South-South ties.

As regards economic foreign policy, neoliberal macro-economic goals have again been combined with a pro-poor focus. For instance, the promotion of outward investment has involved a far more interventionist approach under PT administrations, especially in instances where the Brazilian state has attempted to secure gains in manufacturing (Calvert and Pickup: forthcoming). Brazil's National Economic and Social Development Bank (Banco Nacional do Desenvolvimento Econômico e Social, or BNDES) has played a central role in both domestic and foreign investment strategies, disbursing an average of US\$6.6 billion a year between 2002 and 2012 (Carrillo 2014). Until 2014, Brazil's trade performance was strong throughout the period of PT administration. In 2013, for 
example, Brazil registered a trade surplus of US $\$ 2.384$ billion (Amato 2015). However, gains in trade were largely a product of high global commodity prices, and the overall balance of trade will be significantly affected when these prices fall (Costa, Fritz and Sproll 2015; Carrillo 2014). Far too much reliance has been placed on the commodity boom: while in 2006 Brazil had a trade surplus, with two thirds comprising intermediate or final consumer goods, by 2013 there was a trade deficit in manufactured and semi-manufactured goods of US\$60 billion, and exports were based largely on commodities (Costa, Fritz and Sproll 2015: 21).

The Brazilian New Left has also manifested itself in diplomacy, as well as the extension of development assistance to other countries. Politically, Brazil has 'emerged' in both regional and global terms. Daudelin (2010: 35; author's translation) attributes this activism, based on Brazil's regional dominance, including its denunciation of the attempted Venezuelan coup in 2002, to a 'remarkable centrality' in permanent and ad hoc global clubs. Finally, the PT government has extended development cooperation in the form of technical assistance rather than financial grants, comprising the sharing of best practices, providing qualified personnel, and granting scholarships at Brazilian universities (Burges 2005: 1141). Funding for development cooperation has declined since 2011 (Burges 2014), in tandem with the economic downturn. However, at its high point in 2010, Brazil supported about 300 development projects in 37 countries (ABC online).

The PT's most noted departure from previous foreign policy has been its decision to intensify South-South ties, in various dimensions. As Daudelin (2013: 6) explains,

Since at least the beginning of the twenty-first century, Brazil's relationship with the United States has been the central preoccupation of its foreign policy, and the importance of the 
Foreign Policy of the New Left: Explaining

Brazil's Southern Partnerships

current policy shift lies precisely in the extent to which new partnerships and rivalries displace the United States from that position.

The PT has justified its pursuit of intensified South-South relations by arguing that it will help to correct global asymmetries in power. A speech made by Lula da Silva to welcome the president of Zambia, Rupiah Banda, in 2010 illustrates this logic:

Today, it is the deficit of legitimacy in global governance mechanisms that stands. We have to persist in our effort to reform these decision-making mechanisms, in all areas.... We have to speak with a common voice on the construction of a global order that hears our aspirations for freedom and social justice (quoted in MRE 2010b; author's translation).

Similarly, in another speech made in 2010 to the heads of state of India and South Africa, Lula da Silva described the IBSA (India, Brazil, and South Africa) coalition as 'our response to an unequal and unjust social order incapable of resolving old problems, like extreme poverty' (quoted in MRE 2010a; author's translation). ${ }^{3}$ Examples given by both presidents and their representatives of these inequalities are the composition of the UN Security Council, and voting quotas at the IMF (see, for example, MRE 2015e).

Foreign policy under both the Lula da Silva and Rousseff administrations has focused on promoting social inclusion and eradicating poverty. In his 2010 speech welcoming the president of Zambia, Lula da Silva identified South-South Cooperation as well as multilateralism as the instruments that could achieve these goals (MRE 2010b). Similarly, in a 2015 speech at a meeting to establish the China-Community of Latin American and Caribbean States (CELAC) Forum, Rousseff's minister of foreign affairs, Mauro Vieiro, declared that South-South Cooperation was a 'cooperation modality to which the Brazilian government has unequivocally 
attributed priority, and whose validity and importance are increasingly recognized' (quoted in MRE 2015f; author's translation). However, the emphasis on justice does not mean that the endeavour is simply an ideological one; instead, changing the global power balance is viewed as a way of working in the Brazilian national interest. As Luiz Alberto Figueiredo Machado, a former minister of external relations in the Rousseff administration, stated in 2014 ,

the South-South dimension of our diplomacy has not been an ideological option or an attempt to restore the third-worldism of the past, as some critics insist on characterizing it. It started from, in contrast, a clear diagnostic of the South as an active part of geopolitics and of the global economy (quoted in MRE 2014; author's translation).

As regards trade, the Lula da Silva administration made a 'political choice' to diversify its favoured markets (de Almeida 2013: 20). Mercosul (the Common Market of the South, or Mercado Comum do $\mathrm{Sul}$ ) is a minor exception. Since Mercosul was already regarded as a priority, this only involved a change in intensity (de Oliveira 2010). Other important trading partners include India, South Africa and China. In 2014, trade with India reached US\$11.42 billion, and India became Brazil's eighth most significant trading partner (BRICS Post 2015). Trade with China, which became Brazil's top trading partner in 2009, jumped by 2000\% from 2000 to 2011 (Cardoso 2013), and reached an all-time high of US\$83.3 billion in 2013, before falling 6\% to US\$77.9 billion in 2014 (Conselho Empresarial Brasil-China 2015: 1). South-South investment linkages have also intensified, with Brazil paying increasing attention to Africa, particularly in the natural resources and agricultural sectors (UNCTAD 2010). Large Brazilian corporations (such as Petrobras and Vale) as well as small and medium-sized enterprises (SMEs) are active in 22 African 
countries (BRICS Policy Centre 2014: 11). Muggah and Thompson (2015) estimate that BNDES has invested US\$2.09 billion in Africa since 2007. For example, the BNDES website describes Brazilian participation in several large projects in Mozambique, including the involvement of the construction company Andrade Gutierrez in a US\$320 million dam construction project.

The establishment and consolidation of political blocs with countries in the global South is also an important element of Brazil's foreign policy objective of correcting global power asymmetries. The IBSA formation is aimed at promoting cooperation in diverse areas, and Brazil's participation in the BRICS alliance (the strategic partnership of Brazil, Russia, India, China, and South Africa) has committed it to an array of cooperative initiatives (Cardoso 2013).

The 2014 launch of the BRICS Development Bank is a major development. The Bank "pointedly exclude[s] Northern donors and emphasize[s] a renewed focus on infrastructure' as part of its wider aims of creating alternatives to existing, Western-dominated development funding agencies (Abdenur and da Fonseca 2013: 1482). In the G-20, Brazil has also sought to strengthen political ties with other Southern nations while playing a leadership role, notably in efforts to change agricultural trade policy (Burges 2005). It should be noted that initiatives such as the G-20 or IBSA do not diminish the importance of North-South ties (Burges 2005; Taylor 2009). Indeed, Lula da Silva himself described his aim as " maintaining good political, economic and commercial relations with the great powers, while prioritising the ties with the South at the same time' (da Silva 2007, quoted in Vigevani and Cepaluni 2007: 1321; italics in the original).

Development cooperation - managed by the Brazilian Cooperation Agency (Agência Brasileira de Cooperação, or ABC) - is another significant aspect of Brazil's 'turn to the South'. Rather than 
financial aid, this has taken the form of technical assistance, notably the transfer of best practice distilled in the course of implementing Brazil's successful social policies. For instance, Ventura (2013) notes how Brazilian proposals for 'structural cooperation' in the health sector are based on the assumption that the Brazilian principles of universality, equality, and integral coverage support global models for improving health systems holistically, rather than targeting specific diseases or weaknesses, like the models associated with aid from OECD countries. As Burges (2005) argues, technical assistance is part of a 'psychologically transformative foreign policy agenda in the global South', emphasising the revaluation of Brazilian (and Southern) identity through the projection of self-confidence.

Brazil has developed a truly global reach, with its 'turn to Africa' perhaps partly motivated by impediments to its regional leadership, such as Argentina's refusal to support its bid for a permanent seat on the UN Security Council (Abdenur 2015). Given its association with altruism, development cooperation may seem like the most obvious manifestation of the PT government's quest for global justice, but Vieira has noted that it also contributes to Brazilian self-interest. Cooperation, he argues, "not only strengthens our ties with such countries, but also helps to project Brazilian interests in the world, in a wider form' (quoted in MRE 2015d; author's translation). Machado has similarly stated that South-South Cooperation helps Brazil to project a positive image by increasing its 'diplomatic capital' (quoted in MRE 2014; author's translation).

\section{The global implications of an activist Brazil}

This section examines the impact of Brazil's expanded global presence on its partners. The analysis does not include all the potential advantages and disadvantages of interaction with Brazil's New Left governments, but does underline some of the key 
dynamics. It suggests that, first and foremost, there is a need to disaggregate developing country partners to understand what Brazilian activism means for the world. In doing so, I differentiate between 'other Southern giants', 'Southern states' and 'citizens of the South', not to draw or reify these boundaries, but to initially acknowledge the differentiated potential of countries to take advantage of Brazil's foreign offerings, and the particularities of engagement. For example, while Brazil is relatively disempowered in its relationship with China, I argue that Brazil benefits disproportionately from its ties with other developing countries.

\section{'Other Southern giants'}

As discussed previously, Brazil has forged a number of important partnerships with other emerging powers, including the IBSA and BRICS alliances, and its special relationship with China. Efforts to consolidate linkages with other countries have not only been economic, but also ideological and political. As a result, they have numerous consequences. First, many of these countries follow a state-led politico-economic model, as does Brazil. Lula da Silva's and Rousseff's active encouragement of Brazilian companies to invest abroad, and extensive investments from BNDES, attest to the active involvement of the Brazilian state in business relations (Daudelin 2010; Cervo 2010). Rousseff has, however, exerted greater pressure on the corporate sector to play a leadership role in Brazilian foreign investment (Burges 2014). The domestic significance of a neo-developmentalist state is debated, and several authors have emphasised that the state is not a neutral body that can escape politics (Leftwich 2008; Leiva 2008; Radice 2008). The most obvious problem is that there are limits to how many diverse demands government can satisfy - in the case of Brazil, this has become even harder as the economy has languished. This task 
becomes harder still when government tries to satisfy external as well as domestic interests.

Moreover, does domestic interventionism by emerging states automatically become the model that informs their foreign policy behaviour? Taylor (2009: 46; italics in the original) notes that although these alliances seek a rethink of global power structures, 'the elites from key developing countries demand greater neo-liberalism, not less'. The most obvious example is G-20 lobbying at the WTO for Western countries to abandon their selective protectionist policies and more fully adhere to the WTO regime (Taylor 2009). For example, in a joint declaration following a visit to Brazil by China's prime minister, Li Keqiang, in May 2015, Brazil and China reiterated their 'opposition to any form of protectionism', and their commitment to 'the protection of the common interests of developing countries' (quoted in MRE 2015c; author's translation). However, such common interests cannot be assumed, and the removal of agricultural protectionism is only one example of an issue where there is a lack of consensus among development countries. The conceptually sophisticated enquiry by Nunes de Oliveira, Onuki and Emmanuel de Oliveira (2006) into the basis of South-South coalitions, particularly IBSA, asks whether they are exogenously or endogenously driven, and more offensive or defensive. They argue that although these countries tend to have divergent interests, they could be overcome, although this remains uncertain (Nunes de Oliveira, Onuki and de Oliveira 2006). Despite the demand by emerging powers that global imbalances be corrected, they may seek to reform global power structures in ways that actually deepen the neoliberal project to their benefit - or their objectives may differ widely, thereby hampering or preventing collective action.

Lastly, the partnerships among emerging powers are themselves unbalanced. Chinese-Brazilian business relations have been particularly uneven; while Brazil benefited from a trade surplus in 
2010, more than $80 \%$ of its exports to China were commodities (Doctor 2012: 803). In 2014, exports of soybeans, iron ore and petroleum alone represented $79.8 \%$ of total exports to China (Conselho Empresarial Brasil-China 2015: 4). This trend is particularly worrisome in the context of concern about Brazil's trade composition more generally, and the fact that China is Brazil's top trading partner. This challenge has led to schisms within PT support, as agricultural elites benefit hugely from the partnership, while industry concern mounts, also generating opposition from the PSDB (Cardoso 2013). China's sheer power also detracts from Brazil's political clout. In a sense, it is China who is the regional giant in Latin America. In 2014, Chinese trade with South America totalled US\$174.2billion, compared to Brazil's US\$66.6 billion (MRE 2015a: 2; 2015b: 2). In sum, the potential for Brazil's partnerships with other major powers to positively influence global relations depends on their conceptions of the role of the state in managing their economies, and, more generally, what the various participants wish to achieve from these powerful blocs. Furthermore, the varying capabilities of the emerging powers themselves will affect their influence over bilateral partnerships and other collective undertakings.

\section{'Southern states'}

Despite the PT's stated objective of expanding its relations with other countries of the global South, Brazil's partnerships with less powerful - or more 'average' - Southern states are actually quite limited. In fact, across all areas of engagement, from investment to development cooperation, Brazil seems to neglect those countries that have been historically marginalised. The UNCTAD report entitled South-South Cooperation: Africa and the New Forms of Development Partnership (2010: 106) notes that trade, investment and official flows between African and developing country partners 
tend to occur among 'resource-rich, politically strategic and large countries in the region'. Of course, what defines 'politically strategic' differs among states. Brazil's 'politically strategic' relations have largely been with other lusophone countries, thus replicating Portugal's traditional patterns.

While Brazil is an important export destination for African countries, very few actually export to Brazil. In 2014, only three African countries - Nigeria (55.7\%) Algeria (17.1\%) and Morocco (7.3\%) accounted for $80.1 \%$ of African exports to Brazil (MRE 2015g: 4). The fact that Brazil imports minerals and exports agricultural commodities as well as arms and other military equipment (Abdenur 2015) perpetuates the historically problematic composition of African trade. These sorts of imbalances have led Taylor (2009: 54) to remark that 'talk of automatic win-win solutions arising from South-South trade is economically illiterate, and smacks of infantile Third Worldism'. Nevertheless, relative to other emerging powers, Brazil places less emphasis on access to African resources, given that it is itself an energy superpower (Stolte 2013).

Yet, emancipatory ideas about changing the global order in Brazilian South-South Cooperation discourse and South-South discourse more generally ' ... still have an impact on Brazil's relations with other countries' (Vigevani and Cepaluni 2007: 1318). What Burges (2005) has described as an agenda for revaluing what it means to be Southern is a part of remaking 'global economic geography' (1144; italics in original). The idea of revaluing Southern identity in a positive way is well captured in a report by the World Bank and IPEA $^{4}$ (2011) which notes how 'the new Africa coincides with a global Brazil' (3; italics in original).

Representing a revaluing of identity and as symbolic of solidarity, the forging of greater Southern ties is therefore politically significant. The resulting political influence is difficult to quantify, 
but it does appear to mitigate other negative consequences of Brazilian leadership. In Haiti, for instance, despite Brazil's armed presence and its marginal efforts to promote development, Haitians still expressed a widespread love for Brazilians ${ }^{5}$ (author's interviews 2015). One interesting exception to Brazil's limited engagement with many Southern countries is that, because of the importance it places on sovereignty, it also has ties with countries otherwise regarded as 'pariahs' (Abdenur 2015: 333). Yet these engagements raise important questions around standard-setting, such as whether norms - such as those of 'good governance' - are developed or obstructed (Woods 2008). Rousseff's 2013 announcement that US\$900 million in African debt would be cancelled was 'roundly criticized by the left and right for favouring authoritarian and corrupt African economies' (Muggah and Thompson 2015).

Brazil's relative neglect of the non-emerging South is not ubiquitous, however. Indeed, there are several places where its influence is considerable (Daudelin 2010). As may be expected, Brazil is much more significant in its own backyard, although these relationships are not without tensions. For instance, Brazil has prioritised Mercosul because of the opportunities it offers to Brazilian companies; Brazil accounts for two thirds of the bloc's trade (Briceño Ruiz 2007; Malamud and Gardini 2012). At the same time, Mercosul displays distinct post-neoliberal qualities, following Lula da Silva's initiative to open up space for the participation of social movements (Almeida 2007).

Besides the allocation of funds meant to correct some of the imbalances among members, the bloc has also been the focus of other redistributive concerns. Mercosul Social, designed to support the formulation of social policies at the regional level, played only a limited role in the early years, but has received increased attention since 2000 (Mercosul n.d.; Mercosul Social 2012). These initiatives 
reflect not only Brazil's leadership, but also a broader turn to the Left that many, but not all, countries in Latin America have undergone.

When assessing the outcomes of regional relationships, a key factor is the relationship between regional preponderance and global leadership. As Alden and Vieira (2005) note, there is the assumption that a country must be a regional leader in order to become a real global power, but international recognition could help to consolidate regional authority, guaranteeing the submission of neighbours. Brazil's regional leadership has not been accepted, and has been explicitly resisted (Daudelin 2010).

Brazil's relationship with Haiti is particularly telling of the dilemmas of regional engagement. One problem with raising aspirations about Brazil's leadership is that it can lead to frustrated expectations, and generate resistance (Vigevani and Cepaluni 2007). In Haiti, Brazil had the opportunity to test its principles around security and multilateralism, especially its concern with reconceptualising peacekeeping and enforcement, inter alia by emphasising the economic roots of insecurity (Soares de Lima and Hirst 2006). Brazil has played a leadership role in MINUSTAH, the UN's stabilisation mission in Haiti, since its inception in 2004. Haiti has also been an important beneficiary of Brazilian development cooperation (ABC and BRICS Policy Centre 2013; Cabral and Weinstock 2010). Brazil further scaled up humanitarian support following the 2010 earthquake, an engagement that is important not only for the prestige reason of demonstrating that Brazil is not an impoverished country, but also for the larger foreign-policy reason of staking a direct claim to a seat at major global governance tables' (Burges 2014: 363).

Crucially, peacekeeping and other forms of cooperation signal widening Brazilian influence in the Caribbean, and the simultaneous edging out of the US (Cervo 2010). Brazil's presence in Haiti has not 
gone uncriticised, however; Haitians have displayed increasing hostility to Brazilian troops, and some scholars have argued that Brazil's approach to peacekeeping does not really differ from traditional engagements, displaying a focus on peace enforcement rather than development and reconstruction (Seitenfus 2014). Indeed, initiatives also intersect in important ways, as development cooperation projects have been perceived as compensation for Brazilian leadership of MINUSTAH - a way for Brazilian soldiers to be 'free to do their business without ill will' (anonymous, author's interviews 2015; author's translation). Thus Haiti demonstrates the practical outcome of Brazil's programme of strengthening Southern ties, specifically how this sometimes benefits Brazil to the detriment of its supposed partners.

Brazil's ties with other Portuguese-speaking countries are another exception to the charge that its relations with the South have remained limited, but also illustrate how fraught more intensive cooperation can be. Brazil's relations with other lusophone countries are long-standing; indeed, Petrobras began investing in Angola in 1979 (Abdenur 2015). While Brazil's trade relations are far more diverse (see MRE 2015g), its investments in Africa have focused on southern Africa, especially South Africa, Angola and Mozambique (BRICS Policy Centre 2014). Similarly, Brazilian development cooperation has concentrated on other lusophone countries, with Mozambique a top recipient (BRICS Policy Centre 2014).

Areas where Southern engagement have remained minimal obviously contrast with the PT's stated emphasis on the importance of these links. Similarly, although other Portuguese-speaking nations have generally received much greater attention, these ties have led to other problems. Investments, especially by major Brazilian enterprises, have been criticised for creating social and environmental damage; Vale's operation in Mozambique, for example, has been criticised on the grounds that it did not undertake a 
fair resettlement programme, and that residents were relocated to an area without work opportunities (Marshall 2015).

As regards development cooperation, ProSavannah (a trilateral programme in Mozambique run in partnership with the Mozambican and Japanese governments) has arguably been the most heavily resisted project implemented by the Brazilian government, with community members and activists arguing that it amounts to little more than an instance of land-grabbing (Voz da América 2015).

\section{'Citizens of the South'}

Finally, it is important to consider Brazil's expanded relations with the global South in terms of its consequences for average citizens. In general, these relations are primarily between states, especially as the financial crisis has given Brazil room to promote its more interventionist approach (Abdenur 2015). However, while this politico-economic model has certain benefits, notably a focus on the poorest of the poor, it also holds drawbacks for average citizens in the Global South. Specifically, Brazil's problems in building participatory democracy at home, notably the failure to scale up participatory budgeting to the federal level once the PT had assumed power (de Oliveira 2010), are magnified abroad.

Carrillo (2014) argues convincingly that statist political economies are problematic because vested interests encourage the state to base its support on criteria other than performance. If, as he maintains, the new developmentalist agendas lack mechanisms for accountability and oversight (Carrillo 2014), the PT government's exclusion of Brazilian civil society, and its failure to include foreign civil society organisations in its activities abroad, further aggravate these tendencies. Zibechi (2012) describes various instances of regional resistance to a Brazilian presence, among them incidents in Paraguay where citizens fighting for land reform have confronted Brazilian 
companies. Moreover, Brazil's global support for agribusiness excludes small farmers and the peasantry (Daudelin 2010; Taylor 2009). Nevertheless, Brazilian development cooperation has made some progress in addressing social exclusion and poverty. Its initiatives tend to be based on the same models adopted by successful interventionist domestic programmes, such as those where 'virtuous circles' support local production by guaranteeing the purchase of agricultural products, which are used for feeding programmes in turn (IPEA 2010). However, like the linkages between development cooperation and military engagement in Haiti, Ventura (2013) is critical of their trade-offs; considering health, she writes that, 'publicly run initiatives in the field of health come across as a compensation for the type of South-South cooperation that is based on market interests' (100).

In short, Brazil's engagement with the South has been uneven, including relations where the other country (notably China) effectively holds the upper hand; relations showing detrimental power imbalances that further marginalise the developing country partner or its citizens, such as skewed trade dynamics; and engagements in which Brazil effectively remains irrelevant.

\section{The determinants of Brazilian foreign policy}

This final section explores how foreign policy is made under Brazil's New Left government. Primarily, it seeks to explain why the partnerships described above have been so varied, and why they tend to replicate historical patterns of exclusion, or generate new ones. Conceptually, it also seeks to contribute to an understanding of the linkages between domestic and foreign policy, demonstrating that, despite some overlaps, the determinants of domestic and foreign policy differ from one another. While I argue that the New Left has done more than 'talk left' in its foreign relations, pointing to both the 
domestic and foreign projects of the PT as similarly inadequate in their social aims is of little use in outlining precisely how and why foreign policy has fallen short of New Left principles. Instead, the politicisation of foreign policy in line with PT principles is read as signifying that Southern ties can hold more symbolic weight than suggested by, for example, the extent of trade ties alone. Similarly, the marginalisation of the PT government's social base in making foreign policy decisions helps to explain why Brazilian engagement has been positively received by Southern states, but not necessarily by their citizens.

The activities of the PT government abroad have been supported by a combination of external/structural and 'natural' variables. The proximity of Brazil to the US has played a particularly influential role in Brazilian foreign policy decisions, as has the achievement of relative stability in the region since the early $20^{\text {th }}$ century (Soares de Lima and Hirst 2006). Given its geographic size and population, Brazil also has the potential to become a significant regional and global power (Daudelin 2010).

Internationally, the perceived illegitimacy and inefficiency of global governance systems has created a more receptive space for alternatives to be considered (Daudelin 2010). Moreover, global governance reform seemed more likely following the rise of new powers, notably China. These countries looked to pursue what Vigevani and Cepaluni (2007) refer to as 'autonomy through diversification': an 'adherence to international norms and principles by means of South-South alliances, including regional alliances, and through agreements with non-traditional partners ... trying to reduce asymmetries in external relations with powerful countries' (Vigevani and Cepaluni 2007:1313). In various ways, the external context and key characteristics of Brazil favoured more active foreign policy. 
Brazil's foreign policy decisions have also been influenced by domestic institutional factors, as well as several key constituencies. The relationship between the MRE and the government is a significant factor. In the 1990s, the MRE played an increasingly prominent role as changes such as regional integration and increasingly complex multilateral negotiations demanded skilled diplomacy (Vigevani and Cepaluni 2007). Itamaraty has historically exercised a significant degree of autonomy, maintaining its separation from other ministries and agencies (Cason and Power 2009). A 2001 survey of members of Brazil's 'foreign policy community' identified a strong belief in the idea of its autonomy (de Souza 2001). For instance, one respondent argued that 'Brazil has a very large bureaucracy, and there is little or no democratic oversight ... there is no negotiated agenda with society' (quoted in de Souza 2001: 86-7; translation from Cason and Power 2009). Similar to Lula da Silva, these diplomats have a long-standing interest in intensifying Brazil's presence overseas (Daudelin 2010). Celso Amorim, who served as minister of foreign relations during Lula da Silva's entire presidency (2003-2011), promoted a specific version of this intensification by endorsing and enhancing the president's vision of focusing on other developing countries rather than on the US and Europe (Cardoso 2013: 43). Soares de Lima and Hirst (2006) have also suggested that there is a path dependency at work in Itamaraty in that, once ideas gain legitimacy, they are very difficult to dispel thereafter. This would explain the continued resonance of earlier foreign policy paradigms; even Lula's assertive policy turn is reminiscent of the emphasis on South-South ties under Ernesto Geisel, president from 1974 to 1979 (Vigevani and Cepaluni 2007).

A striking feature of foreign policy formation under the PT government is that it has been subject to domestic debate (Vigevani and Cepaluni 2007). Historically, foreign policy design has been seen as detached from public opinion (Daudelin 2010). Under Lula, 
however, opposition parties, especially the PSDB and the Liberal Front Party (Partido da Frente Liberal, or PFL), were concerned about what a perceived lack of effort to maintain relations with traditional allies would generate (Vigevani and Cepaluni 2007). In part, the heightened politicisation of foreign policy is explained by processes of pluralisation, influenced by changes such as Brazil's return to democracy (Cason and Power 2009). Cason and Power (2009) have argued that, under Cardoso and Lula da Silva, policy-making was marked by two trends: 'the pluralization of actors, and the advent of presidentially led diplomacy' (119; italics in the original). The first trend involved greater civil society participation. However, under Lula da Silva's administration, both trends were also strongly associated with the politicisation of foreign policy in line with PT beliefs and principles, where policy reflects the PT agenda rather than neutral ideas promoted by the civil service. Again, despite Lula da Silva's continuation of previous macroeconomic policies, analysts have argued that 'it is in foreign relations and international politics that the Lula government most resembles the discourse of the PT' (de Almeida 2004: 162; translated from Cason and Power 2009). While the validity of this statement is another issue, it is important to recall that foreign policy features prominently on the PT governance agenda. Brazil's leading role in trade talks is one example. Meeting with the G-20 to prepare for WTO trade talks, Lula da Silva sought to address policies that largely disfavoured the South. As he declared in 2003, 'endowed with legitimacy and representativeness, the G-20 is changing the dynamics of multilateral trade diplomacy... the G-20 helps to prevent the parameters of the agriculture debate in the WTO from being imposed by the protectionist interests of a few members' (da Silva, quoted in Cason and Power 2009: 130).

In general, the discourse around correcting global asymmetries resonates with PT ideology about anti-imperialism (Cason and 
Power 2009) and the realisation of human rights, including via poverty reduction. In this way, 'the government's fight against poverty and unequal income distribution at home and its assertive and activist foreign policy can be viewed as two sides of the same coin' (Soares de Lima and Hirst 2006: 21). Placing a PT branding on activities abroad also helps to explain why the MRE has lost some of its autonomy, and why foreign policy has become an area of greater democratic contention.

An examination of the determinants of the 'Southern turn' must also include an examination of some of the key constituencies influencing foreign policy decisions. For instance, de Oliveira (2010: 138) claims that, beyond presidential charisma or an engaged Itamaraty, foreign policy also 'reflects the new situation and interests that are well-founded in modern Brazil. The emergence of new elites has led Brazil to stop being a rule-taker'. The importance of foreign policy for the PT on an ideological level thus cannot obscure the pragmatic aspects of active regional and global engagement. Rather than business elites being marginalised under PT administrations, their influence - especially agricultural and export interests - has been extended (Cason and Power 2009). This was clearly reflected in a number of appointments made by Lula da Silva, notably that of Luiz Fernando Furlan to the Ministry of Agriculture and Roberto Rodrigues to the Ministry of Development, Industry and Foreign Trade, which 'served as direct communication channels to agricultural interests and exporters' (Cason and Power 2009: 128). Nonetheless, the dominance of an agribusiness elite is not universal. For example, involvement in Mercosul has consistently benefited Brazil's manufactured goods and services (de Oliveira 2007). Moreover, many groupings are clearly harmed by trade with China which is greatly skewed in favour of the latter party, resulting in cheap manufactured goods flooding into Brazil (Cervo 2010; de Almeida 2013). However, the major bias towards natural resources in Brazilian exports underlines the importance of these actors. 
The PT government's activities abroad have also marginalised its domestic social base. Domestically, the PT has largely been supported by urban social movements and labour unions, which has allowed the PT administration to neglect rural demands (de Castro and Motta 2015). In principle, these interests groups should be equally supportive of the government's domestic and foreign conduct, or perhaps even more satisfied with foreign policy, if claims that the government's activities abroad are driven by PT values are accurate. For instance, de Oliveira (2006) acknowledges that, once the PT had assumed power, its progress towards greater social justice, inter alia by introducing participatory structures, was much more limited than previous local and state experiences would have suggested. However, he maintains that efforts to 'export' social policies to other countries, such as to Haiti, have had largely positive results: 'an alternative to occupation and food distribution, Brazil's actions in Haiti have engaged the best of its social and development policies' (de Oliveira 2006: 131). These initiatives appear to reflect the values and demands of Brazilian social movements and labour unions, which generally call for a more interventionist, protectionist state via the extension of social coverage, labour market inclusion, and the promotion of participatory governance.

However, there are many more tensions surrounding Brazil's activities abroad than these observations would suggest. For example, citizens of, and civil society groupings in target countries have criticised BNDES investments on the grounds that they are socially and environmentally harmful (Ventura 2013). While social participation chimes with PT ideology, Brazil's foreign programmes and projects have not necessarily involved or gained the support of these actors. In particular, Brazilian-led programmes have not engaged with civil society organisations, despite the contention, by civil society actors as well as the Brazilian state, that they are based on successful domestic policies that have depended on civil society mobilisation and involvement (Pickup 2015). 
In sum, current Brazilian foreign policy has been determined by a shifting institutional environment, and changed relations between state and society. These determinants are distinct from those determining domestic policy, which means that the PT's foreign policy and its global implications cannot automatically be understood on the basis of its domestic conduct. Moreover, each determinant of foreign policy sheds light on the dimensions of Brazil's engagement with the global South. However, this analysis only captures the general dynamics of foreign policy-making. Indeed, more specific case studies or sectoral analyses would reveal in detail which pressure groups influence policy, how they do so, and under what conditions particular actors are able to exert their influence. Viera's 2013 article on Brazilian foreign policy in the context of global climate norms provides an important model, as he describes in detail how the domestic debate about climate change has shifted over time.

\section{Conclusion: the many faces of Brazilian activism abroad}

This article has explored the implications of the rise of the New Left in Brazil for the rest of the world, with particular reference to the PT government's efforts to strengthen Brazil's ties with the global South. After summarising domestic economic and social policy under successive PT administrations, it has presented the main characteristics of current Brazilian foreign policy, notably the emphasis on cultivating relations with the global South.

I have examined the effects of this 'turn to the South' by exploring what Brazil's economic and diplomatic relations, as well as development cooperation, have meant for different partners. In particular, by disaggregating 'the South', the implications of Brazilian engagement come to the fore. At one extreme, an emerging 
power like China has the upper hand in its interactions with Brazil, while peasants in other countries are disadvantaged by Brazil's actions in the interests of an agribusiness elite.

The article has also traced several important institutional and interest-related determinants of Brazilian foreign policy, and found that, while demonstrating some overlaps with the drivers of domestic policy, they also contain their own particularities. Specifically, factors such as Itamaraty's historic autonomy and the low but growing level of interest in foreign policy in Brazilian society at large have helped to shape its Southern partnerships, including their negative impacts such as the environmental and social harms associated with Brazilian investments.

In short, there is no coherent project of Southern engagement, because of the particular combination of institutions and interests behind foreign policy-making in Brazil. Institutional barriers to participation in decision-making have decreased, but the interests of the powerful agribusiness sector, with little counterbalancing from civil society, seem to prevail. As a result, Brazil's current programme of Southern engagement contradicts its stated objective of acting as a benevolent global power that can help to correct global asymmetries. To conclude, while Brazil's programme of South-South Cooperation does not just present a continuation of the previous foreign policy order, it also does not present a real alternative to the neoliberal global order, as suggested in its South-South rhetoric.

\section{Acknowledgements}

I would like to thank Stephen Brown, Zoe Phillips Williams, and the anonymous reviewers for their helpful comments on previous drafts. 


\section{References}

Agência Brasileira de Cooperação (ABC). [online]. Coordenação geral de cooperação técnica entre países em desenvolvimento. Available at:http://www.abc.gov.br/SobreAbc/Direcao/CGPD [accessed on $23 \mathrm{Apr}$ 2015].

ABC and BRICS Policy Centre. 2013. O Brasil e a Cooperação Sul-Sul. Available at: http://bricspolicycenter.org/homolog/Event/Evento/596 [accessed on 23 Apr 2015].

Abdenur, Adriana. 2015. 'Organisation and politics in South-South cooperation: Brazil's technical cooperation in Africa'. Global Society, 29: 321-338.

Abdenur, Adriana and João Moura Marques da Fonseca. 2013. 'The North's growing role in South-South Cooperation: keeping the foothold'. Third World Quarterly, 34: 1475-1491.

Alden, Chris and Marco Antonio Vieira. 2005. 'The new diplomacy of the South: South Africa, Brazil, India and trilateralism'. Third World Quarterly, 26: 1077-1095.

Amato, Fábio. 2015. 'Balança comercial registra em 2014 primeiro déficit desde 2000'. Globo [online] Available at: http://g1.globo.com/economia/ noticia/2015/01/balanca-comercial-registra-em-2014-primeiro-deficit-desde2000.html [accessed on 7 Jan 2016].

Bin, Daniel. 2014. 'The class character of macroeconomic policies in Brazil of the Real'. Critical Sociology, 40: 431-449.

BNDES. n.d. Consulta a financiamentos de exportação para obras no exterior. Available at: http://www.bndes.gov.br/SiteBNDES/bndes/bndes_pt/ Institucional/BNDES_Transparente/consulta_as_operacoes_exportacao/pain el_consulta_pos_embarque_obras.html [accessed on 8 Jan 2016].

Boito, Armando and Tatiana Berringer. 2014. 'Social classes, neodevelopmentalism, and Brazilian foreign policy under Presidents Lula and Dilma'. Latin American Perspectives, 198: 95-109. 
Braig, Marianne, Timothy J Power and Lucio Rennó. 2015. 'Brazil 2015 and beyond: the aftermath of the 2014 elections and implications for Dilma's second term'. LASAForum XLVI: 15-17.

Briceño Ruiz, José. 2007. 'Strategic regionalism and regional social policy in the FTAA process'. Global Social Policy, 7: 294-315.

BRICS Policy Centre. 2014. 'Solidarity among brothers? Brazil in Africa: trade, investment and cooperation'. Available at: http://bricspolicycenter. org/homolog/uploads/trabalhos/6418/doc/1074485311.pdf [accessed on 7 Jan 2016].

The BRICS Post. 2015. 'Brazil, India vow to tap 'vast potential' in trade ties'. Available at: http://thebricspost.com/brazil-india-vow-to-tapvast-potential-in-trade-ties/\#.VoOrZpMrL6A [accessed on 7 Jan 2016].

Burges, Sean. 2014. 'Brazil's international development co-operation: old and new motivations'. Development Policy Review, 32: 355-374.

_. 2005. 'Auto-estima in Brazil'. International Journal, 60: 1133-1151.

Burity, Joanildo A. 2006. 'Reform of the state and the new discourse on social policy in Brazil'. Latin American Perspectives, 33: 67 - 88. Translated by L Hallewell.

Cabral, Lídia and Julia Weinstock. 2010. Brazilian Technical Cooperation for Development: Drivers, Mechanics and Future Prospects. London: Overseas Development Institute.

Calvert, Julia and Megan Pickup. Forthcoming. 'The politics of investment in the Americas: Canada, Brazil, and the (post-) neoliberal state'. Canadian Journal of Foreign Policy.

Cameron, Maxwell A. 2009. 'Latin America's left turns: beyond good and bad'. Third World Quarterly, 30: 331-348.

Cardoso, Daniel. 2013. 'China-Brazil: a strategic partnership in an evolving world order'. East Asia, 30: 35-51.

Carrillo, Ian. 2014. 'The new developmentalism and the challenges to long-term stability in Brazil’. Latin American Perspectives, 198: 59-74.

Cason, Jeffrey W and Timothy J Power. 2009. 'Presidentialization, pluralization, and the rollback of Itamaraty: explaining change in Brazilian 
Foreign Policy of the New Left: Explaining

Brazil's Southern Partnerships

foreign policy making in the Cardoso-Lula era'. International Political Science Review, 30: 117-140.

Cervo, Amado Luiz. 2010. 'Brazil's rise on the international scene: Brazil and the world'. Revista Brasileira de Política Internacional, 53.

Conselho Empresarial Brasil-China. 2015. China Brazil update. Available at: http://cebc.com.br/sites/default/files/china-brazil_update_v.final_oficial.pdf [accessed on 6 Jan 2016].

Costa, Sérgio, Barbara Fritz and Martina Sproll. 2015. 'Dilma 2.0: from economic growth with distribution to stagnation and increasing inequalities?' LASAForum XLVI: 21-24.

Daudelin, Jean. 2013. 'Coming of age? Recent scholarship on Brazilian foreign policy'. Latin American Research Review, 48: 204-217.

2010. 'Le Brésil comme puissance: portée et paradoxes'. Problèmes d'Amérique Latine, 78: 29-46.

de Almeida, Paulo Roberto. 2013. 'Brazilian trade policy in historical perspective: constant features, erratic behaviour'. Revista de Direito Internacional, 10: 11-27.

. 2004. 'Uma política externa engajada: a diplomacia do governo Lula'. Revista Brasileira Política Internacional, 47: 162-184.

de Castro, Fábio and Renata Motta. 2015. 'Environmental politics under Dilma: changing relationships between the civil society and the state'. LASA Forum XLVI: 25-27.

de Oliveira, Marcos Aurelio Guedes. 2010. 'Sources of Brazil's counter-hegemony'. Revista Brasileira de Política Internacional, 53: 125-141.

de Oliveira, Amâncio Jorges Nunes, Janina Onuki and Emmanuel de Oliveira. 2006. 'Coalizões Sul-Sul e Multilateralismo: Índia, Brasil e África'. Contexto Internacional, 28: 465-504.

de Souza, Amaury. 2001. A agenda internacional do Brasil: um estudo sobre a comunidade brasileira de política externa. Rio de Janeiro: Centro Brasileiro de Relações Internacionais.

Doctor, Mahrukh. 2012. 'Brazil's new government and trade: an evaluation of policy and performance'. Critical Sociology 38: 799-807. 


\section{Megan Pickup}

Douglas, Bruce. 2015. 'Brazil activists to walk 600 miles for free markets, lower taxes and privatisation'. The Guardian. Available at: http://www.theguardian.com/ world/2015/apr/24/brazil-activists-marchfree-markets-margaret-thatcher-rand-paul [accessed on 4 Aug 2015].]

Globo. 2015. Brasil autoriza permanência definitiva a 44 mil refugiados haitianos. Available at: http://g1.globo.com/distrito-federal/noticia/ 2015/11/brasil-autoriza-permanencia-definitiva-44-mil-refugiados-haitianos. html [accessed on 6 Jan 2016].

IPEA. 2010. Brazilian cooperation for international development 2010. Brasília: IPEA.

La Botz, Dan. 2015. 'Brazil: Lula, Rousseff, and the Workers Party establishment in power'. New Politics, 15: 53-60.

Leftwich, Adrian. 2008. 'Developmental states, effective states and poverty reduction: the primacy of politics'. UNRISD Flagship Report: Combating Poverty and Inequality. Available at: http://www.unrisd.org/80256B3 C005BCCF9/httpNetITFramePDF?ReadForm\&parentunid=EE2D4DF653F6 077BC1257A5D004C7E5E\&parentdoctype $=$ paper \&netitpath $=80256 \mathrm{~B} 3 \mathrm{C} 00$ 5BCCF9/\%28httpAuxPages\%29/EE2D4DF653F6077BC1257A5D004C7E5 E/\$file/Leftwichweb.pdf [accessed on 5 Aug 2015].

Leiva, Fernando Ignacio. 2008. 'Towards a critique of Latin American neostructuralism'. Latin American Politics \& Society, 50: 1-25.

Leubolt, Bernhard. 2013. 'Institutions, discourse and welfare: Brazil as a distributional regime'. Global Social Policy, 13: 66-83.

Levitsky, Stephen and Kenneth M Roberts (eds). 2011. The Resurgence of the Latin American Left. Baltimore: John Hopkins University Press.

Malamud, Andrés and Gian Luca Gardini. 2012. 'Has regionalism peaked? The Latin American quagmire and its lessons'. The International Spectator: Italian Journal of International Affairs, 47: 116-133.

Marshall, Judith. 2015. 'The worst company in the world'. Jacobin 19 [online] Available at: https://www.jacobinmag.com/2015/11/vale-corporationbrazil-mining-lula-mozambique-brics/ [accessed on 8 Jan 2016].

Mello e Silva, Leonardo. 2014. 'The state, unions, and work reorganization: lessons from today's Brazil'. Latin American Perspectives, 198: 22-41. 
Foreign Policy of the New Left: Explaining

Brazil's Southern Partnerships

Mercosul. n.d. Saiba mais sobre o MERCOSUL. Ministério das Relações Exteriores. Available at: http://www.mercosul.gov.br/saiba-maissobre-o-mercosul [accessed on 9 Aug 2015].

Mercosul Social. 2012. Linha do tempo. Instituto Social de Mercosur. Available at: http://ismercosur.org/pt-br/mercosulsocial/?doing_ wp_cron=1365988448.3468420505523681640625 [accessed on 9 Aug 2015].

Morais, Lecio and Alfredo Saad-Filho. 2011. 'Brazil beyond Lula: forging ahead or pausing for breath?' Latin American Perspectives, 177 (38): 31-44.

MRE. 2015a. América do Sul x China: intercâmbio comercial. Available at http://www.investexportbrasil.gov.br/sites/default/files/publicacoes/indicador esEconomicos/ICAmericaDoSul_China.pdf [accessed on 7 jan 2016].

.2015b. América do Sul: intercâmbio comercial com o Brasil. Available at http://www.investexportbrasil.gov.br/sites/default/files/publicacoes/ indicadoresEconomicos/ICBrasilXAmericaDoSul.pdf [accessed on 7 Jan 2016].

.2015c. Declaração conjunta entre o governo da Republica Federativa do Brasil e o governo da Republica Popular da China alusiva a visita do primeiro-ministro do Conselho de Estado, Li Keqiang. Available at: http://www.itamaraty.gov.br/index.php?option=com_content\&view=article \&id=9694:declaracao-conjunta-e-plano-de-acao-conjunta-visita-do-primeiroministro-do-conselho-de-estado-da-republica-popular-da-china-li-keqiang-br asilia-19-de-maio-de-2015\&catid=42\&lang=pt-BR\&Itemid=280 [accessed on 8 jan 2016].

2015d. Discurso do Ministro Mauro Vieira em Audiência Pública na Comissão de Relações Exteriores e Defesa Nacional do Senado Federal Brasília, 24 de marco de 2015. Available at: http://www.itamaraty. gov.br/index.php?option=com_content $\&$ view=article\&id=8442:pronunciam ento-do-ministro-das-relacoes-exteriores-embaixador-mauro-vieira-em-audie ncia-publica-na-comissao-de-relacoes-exteriores-e-defesa-nacional-do-senad o-federal-24-de-marco-de-2015\&catid=194\&lang=pt-BR\&Itemid=454 [accessed on 8 Jan 2016].

2015e. Discurso do Ministro Mauro Vieira na plenária da IV Cúpula América do Sul-Países Árabes (ASPA) - Riade, 11 de novembro de 2015. Available at: http://www.itamaraty.gov.br/index.php?option=com content \&view=article \&id=12368: discurso-do-ministro-mauro-vieira-por-oca siao-do-almoco-em-homenagem-a-suas-altezas-imperiais-principe-e-princes 


\section{Megan Pickup}

a-akishino-do-japao-brasilia-6-de-novembro-de-2016\&catid=194\&lang=ptBR\&Itemid=454 [accessed on 8 Jan 2016].

2015f. Discurso do Ministro Mauro Vieira na Reunião do Foro CELAC-China.Available at: http://www.itamaraty.gov.br/index.php? option=com_content $\&$ view $=$ article $\&$ id $=6522$ :discurso-do-ministro-mauro-vi eira-na-i-reuniao-do-foro-celac-china \&catid=42\&lang=pt-BR\&Itemid=280 [accessed on 8 Jan 2016].

2015g. Intercâmbio comercial Brasil-África. [online] Available at: http://www.investexportbrasil.gov.br/sites/default/files/publicacoes/indicador esEconomicos/ICBrasilXAfrica.pdf [accessed on 7 Jan 2016].

2014. Palestra Magna do Ministro LuizAlberto Figueiredo Machado por ocasião da III Conferência sobre Relações Internacionais, UnB - Brasília, 27 de novembro 2014. Available at: http://www.itamaraty.gov.br/index.php? option=com_content \&view=article \&id=608:palestra-magna-do-sr-ministrode-estado-das-relacoes-exteriores-por-ocasiao-da-iii-conferencia-sobre-relac oes-internacionais-unb-brasilia-27de-novembro-de-2014\&catid=194\&lang= pt-BR\&Itemid=454 [accessed on 8 Jan 2016].

2010a. Discurso do Presidente de República, Luiz Inácio Lula da Silva, por ocasião da abertura da Sessão Plenária da $4^{a}$ Cúpula do Ibas - Palácio Itamaraty, 15 de abril de 2010. Available at: http://www.itamaraty.gov.br/ index.php?option=com_content\&view $=$ article \&id=9241:discurso-durante-ab ertura-da-sessao-plenaria-da-4-cupula-do-ibas-palacio-itamaraty-brasilia-1504-2010\&catid=197\&lang=pt-BR\&Itemid=448 [accessed on 8 Jan 2016].

2010b. Discurso do Presidente de República, Luiz Inácio Lula da Silva, por ocasião da abertura da visita do Presidente da Zâmbia, Rupiah Banda, ao Brasil-Brasília, 18 de novembro de 2010. Available at: http://www.itamaraty. gov.br/index.php?option=com_content $\&$ view=article \&id=5933:discurso-dopresidente-da-republica-luiz-inacio-lula-da-silva-por-ocasiao-da-visita-do-pr esidente-da-zambia-rupiah-banda-ao-brasil-brasilia-18-de-novembro-de-201 0\&catid=197\&Itemid=448\&lang=pt-BR [accessed on 8 Jan 2016].

Muggah, Robert and Nathan Thompson. 2015. 'What is Brazil really doing in Africa?' The World Post [online]. Available at: http://www.huffingtonpost. com/robert-muggah/what-is-brazil-really-doi_b_6413568.html [accessed on 7 Jan 2016].

Pickup, Megan. 2015. 'Ambiguity and emerging powers: Brazilian development assistance in a changing world order'. Paper presented at the 
Foreign Policy of the New Left: Explaining

Brazil's Southern Partnerships

Canadian Political Studies Association Annual Conference. Ottawa, June 2-4, 2015. Available at: ftp://209.183.10.27/assocsrv/cpsa-acsp/2015event/ Pickup-Megan.pdf [accessed on 29 Oct 2015].

Pitts, Bryan. 2015. 'Who's protesting in Brazil and why?' North American Congress on Latin America (NACLA). Available at: https://nacla.org/ news/2015/04/09/who\%E2\%80\%99s-protesting-brazil-and-why [accessed 3 Aug 2015].

Radice, Hugo. 2008. 'The developmental state under global neoliberalism'. Third World Quarterly, 29: 1153-1174.

Rennó, Lucio. 2015. 'The Brazilian 2014 presidential elections: a country fractured by class struggle?' LASAForum XLVI: 18-20.

Rohter, Larry. 2010. Brazil on the Rise: The Story of a Country Transformed. New York: St Martin's Press.

Seitenfus, Ricardo. 2014. Haiti: Dilemas e Fracassos Internacionais. Ijuí: Editora UNIJUÍ.

Soares de Lima, Maria Regina and Mônica Hirst. 2006. 'Brazil as an intermediate state and regional power: action, choice and responsibilities'. International Affairs, 82: 21-40.

Stolte, Christina. 2013. 'Brazil in Africa: seeking international status, not resources'. Harvard International Review, 34 (4): 63-67.

Taylor, Ian. 2009. 'The South will rise again'? New alliances and global governance: The India-Brazil-South Africa Dialogue Forum'. Politikon, 36: 45-58.

United Nations Conference on Trade and Development (UNCTAD). 2010. 'South-South Cooperation: Africa and the new forms of development partnership'. In Economic Development in Africa Report, 2010. New York: UN.

Ventura, Deisy. 2013. 'Public health and Brazilian foreign policy'. International Journal on Human Rights, 19: 95-113.

Vieira, Marco A. 2013. 'Brazilian foreign policy in the context of global climate norms'. Foreign Policy Analysis, 9: 369-386. 


\section{Megan Pickup}

Vigevani, Tullo and Gabriel Cepaluni. 2007. 'Lula's foreign policy and the quest for autonomy through diversification'. Third World Quarterly, 28: 1309-1326.

Voz da América. 2015. 'Governo moçambicano vai aprovar Prosavana, mas persistem críticas'. Notícias Moçambique. [online]. Available at: http://www.voaportugues.com/content/governo-mocambicano-vai-aprovar-p rosavana-mas-persistem-criticas/2777375.html [accessed on 06.01.2016].

Weyland, Kurt. 2010. 'The performance of leftist governments in Latin America: conceptual and theoretical issues'. In Kurt Weyland, Raul L Madrid and Wendy Hunter (eds), Leftist Governments in Latin America: Successes and Shortcomings. Cambridge: Cambridge University Press: 1-27.

Woods, Ngaire. 2008. 'Whose aid? Whose influence? China, emerging donors and the silent revolution in development assistance'. International Affairs, 84: 1205-1221.

Zibechi, Raul. 2012. The new Brazil: regional imperialism and the new democracy. Oakland, CA: AK Press.

\section{NOTES}

1. The term 'New Left' is used to refer to left-wing governments in Latin America, specifically the PT government in Brazil, and not to other left elements such as civil society organisations and social movements.

2. The scandal involves kick-backs paid to politicians by the state-owned oil company Petrobras for awarding contracts on a preferential basis (Pitts 2015).

3. In another example that also captures continuities with the Rousseff administration, Vieira remarked at the Fourth South American-Arab Country Summit in 2015 that 'we will work together towards a more just and equal international trade, as well as the democratization of international organizations, so that the voice of developing countries can be better heard' (quoted in MRE 2015e; author's translation).

4. Brazil's Institute for Applied Economic Research (Instituto de Pesquisa Econômica Aplicada). 
5. These perceptions are not static. As one reviewer pointed out, Haitians' perceptions of Brazil will continue to be shaped by their experiences after migrating to Brazil. Humanitarian migration flows have increased in recent years, and in November 2015 the Brazilian government announced that permanent residency visas would be granted to about 43000 Haitians (Globo 2015).

\section{About the Author}

Megan Pickup is a PhD Candidate in political science at Carleton University, Ottawa, Canada. Megan has a Master's in Globalization and International Development from the University of Ottawa, and a Bachelor's with Honours in Global Studies from Trent University, Peterborough, Canada. Her doctoral project examines Brazilian humanitarian and development cooperation with Haiti, and is funded by the Social Sciences and Humanities Research Council. Her broader research interests include: South-South Cooperation, foreign aid, Brazilian foreign policy, political economy, post-neoliberalism, and development. She has also been published in Studies in Political Economy, and has a forthcoming article in the Canadian Foreign Policy Journal (with Julia Calvert). She can be reached at megan.pickup@carleton.ca. 